\title{
Molecular MRI of myocardial peroxidase activity in ischemic injury reveals a chemical milieu incompatible with stem cell survival
}

\author{
Howard H Chen ${ }^{1,2^{*}}$, Y Iris Chen ${ }^{1}$, Christian T Farrarr', Eric M Gale ${ }^{1}$, Peter Caravan', Ronglih Liao ${ }^{3}$, John W Chen ${ }^{4}$, \\ David E Sosnovik ${ }^{1,2}$
}

From 19th Annual SCMR Scientific Sessions

Los Angeles, CA, USA. 27-30 January 2016

\section{Background}

The delivery of stem cells to the myocardium after ischemic injury has the potential to prevent left ventricular remodeling and heart failure. Ischemic injury, however, elicits a robust inflammatory response and the release of cytotoxic substances from infiltrating leucocytes. We aimed here to use a myeloperoxidase activatable gadolium chelate (MPO-Gd) [1], to quantify peroxidase activity in the myocardium in vivo after ischemic injury. We further aimed to determine, using bioluminescence imaging, whether the detected levels of MPO were compatible with cell survival.

\section{Methods}

T1 mapping was performed in mice $(n=5)$ at $9.4 \mathrm{~T} 24$ hours after occlusion of the left coronary artery. The mice were injected IV with $0.2 \mathrm{mmol} / \mathrm{kg}$ of MPO-Gd and imaged for 2 hours. An ECG gated Look-Locker sequence was used with the following parameters: FOV $2.5 \mathrm{~cm}$, matrix $160 \times 160$, slice $1 \mathrm{~mm}$, flip angle 20 degrees, TR 3s, TE $1.5 \mathrm{~s}, 4$ averages, TI increment $=\mathrm{RR}$ interval. T1 maps (Matlab) were converted to relaxation rate (R1) maps and the relaxivity (r1) of MPO-Gd at 9.4T was used to convert these into Gd-MPO concentration maps. MPO activity maps were subsequently derived based on the kinetic properties of the enzyme and probe. Bioluminescence imaging (BLI) of luciferase-expressing cardiac side population progenitor cells was performed with the cells exposed to the range of MPO concentrations detected in vivo. Serial BLI of mice injected with cells on day $0(n=7)$ or day 14 $(\mathrm{n}=7)$ after ischemic injury was performed.

\section{Results}

Within 1 hour of injection unbound Gd had washed out of the blood pool and myocardium. Activated Gd-MPO, however, was retained in the injured myocardium well beyond 2 hours (Figure 1). The concentration of activated probe ranged between 0.2 and $0.5 \mathrm{mM}$ (Figure 1C), corresponding to 3-8 activity units of MPO. Cell phantoms (Figure 2A-B) revealed that this range of activity eliminated $80-100 \%$ of BLI signal (cell viability) within 30 minutes. Cells injected into mice on day 0 (Figure 2C-E), when MPO levels were high survived poorly. Survival was significantly improved $(\mathrm{p}<0.05)$ when cells were injected into the myocardium on day 14 , once MPO levels had dropped.

\section{Conclusions}

MPO activity can be quantified in vivo using an activatable Gd probe. The levels of MPO encountered in healing ischemic myocardium are highly cytotoxic and are not compatible with the survival of injected cells. This has major implications for the use of cell therapy in acute ischemic injury.

\footnotetext{
Authors' details

${ }^{1}$ Martinos Center for Biomedical Imaging, Department of Radiology, Massachusetts General Hospital, Harvard Medical School, Boston, MA, USA. ${ }^{2}$ Cardiovascular Research Center, Cardiology Division, Massachusetts General Hospital, Harvard Medical School, Boston, MA, USA. ${ }^{3}$ Cardiac Muscle Research Laboratory, Divisions of Cardiology and Genetics, Brigham and Woman's Hospital, Harvard Medical School, Boston, MA, USA. ${ }^{4}$ Center for Systems Biology, Massachusetts General Hospital, Harvard Medical School, Boston, MA, USA.
} 


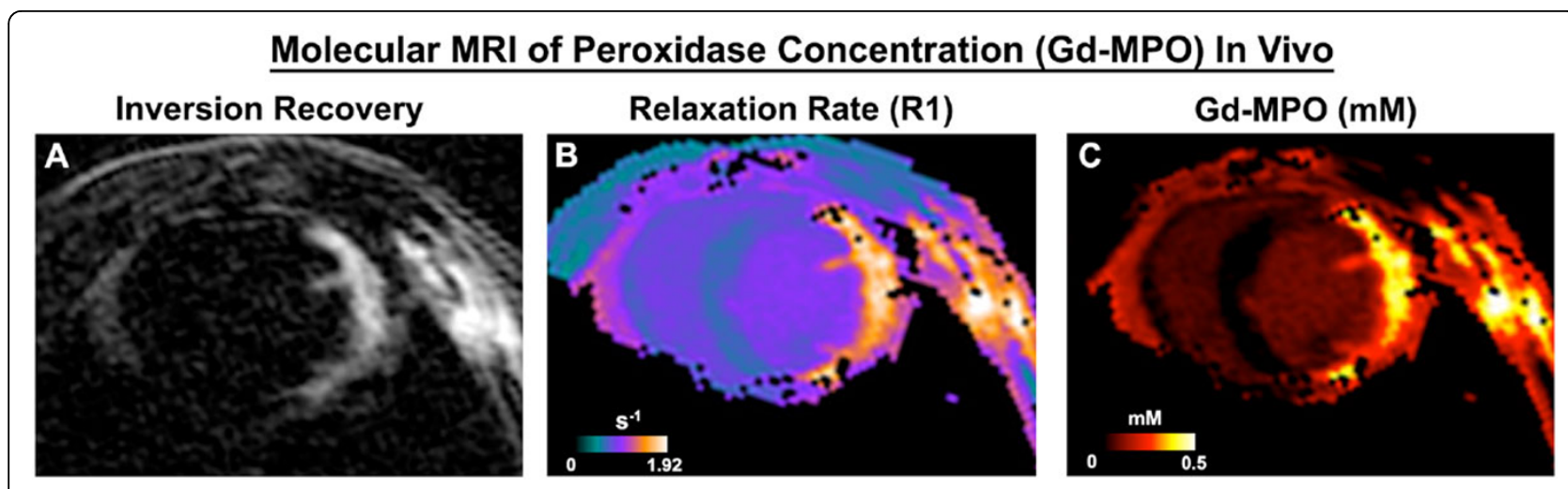

Figure 1 Molecular MRI of Gd-MPO activation in vivo. A. Inversion recovery image 2 hours after probe injection. Unbound Gd has been washed out but activated probe is retained in the ischemic myocardium. B. R1 map of the same slice. C. Quantitative map of Gd-MPO concentration and activity in vivo.

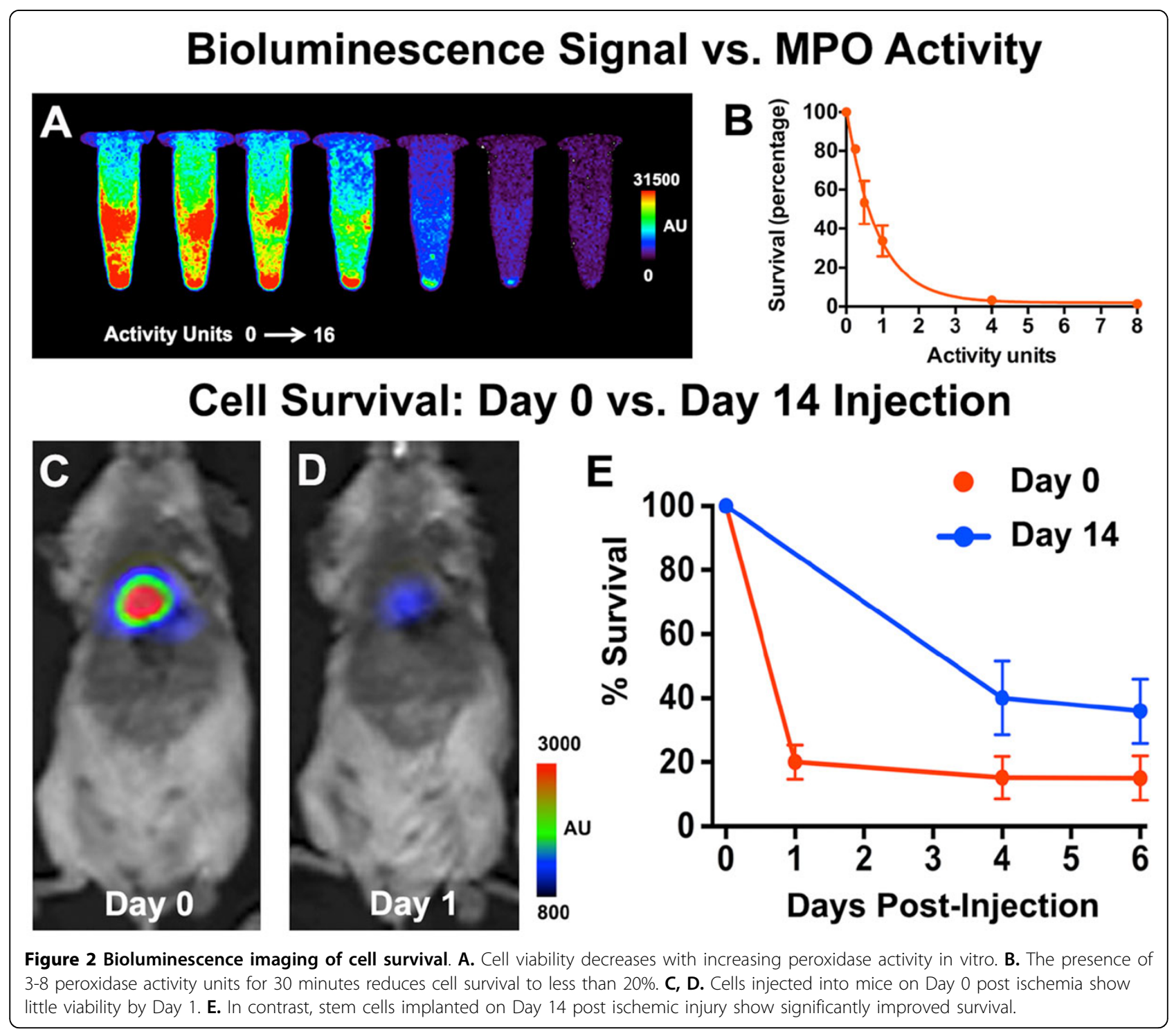


Published: 27 January 2016

\section{Reference}

1. Chen F, Suzuki Y, Nagai N, Peeters R, Coenegrachts K, Coudyzer W, et al: Visualization of Stroke with Clinical MR Imagers in Rats: A Feasibility Study. Radiology 2006, 233(3).

\section{doi:10.1186/1532-429X-18-S1-016}

Cite this article as: Chen et al:: Molecular MRI of myocardial peroxidase activity in ischemic injury reveals a chemical milieu incompatible with stem cell survival. Journal of Cardiovascular Magnetic Resonance 2016

18(Suppl 1):O16.

Submit your next manuscript to BioMed Central and take full advantage of:

- Convenient online submission

- Thorough peer review

- No space constraints or color figure charges

- Immediate publication on acceptance

- Inclusion in PubMed, CAS, Scopus and Google Scholar

- Research which is freely available for redistribution

Submit your manuscript at www.biomedcentral.com/submit

() Biomed Central 